\title{
Perspective
}

\section{Sharing the benefits of biodiversity: some perspectives from the recent history of conservation}

\author{
JEFFREY A. MCNEELY
}

$\mathrm{N}$ ineteen fifty-three was a revolutionary year for biology. James Watson and Francis Crick discovered the structure of DNA. This led to thousands of scientists and vast amounts of money being devoted to laboratory studies of DNA, genes, RNA and the other building blocks of life. Scientists quickly built on the importance of genes to make a series of breakthroughs that led to genetic engineering, genomics, synthetic biology and a better understanding of biological systems.

Meanwhile, genes, species, and ecosystems in the wild were suffering. In 1979 Norman Myers' influential book The Sinking Ark was published, calling attention to the increasing rate of the loss of species, the genes they contain and the ecosystems they support. Just when laboratory scientists were beginning to understand life, unique species were being snuffed out.

The growing awareness of how fast species were being lost drew on the work of biologists such as Paul Ehrlich, George Schaller, Salim Ali, Tom Lovejoy, Terry Erwin and others. One significant result was the launching of a new mission-driven discipline, conservation biology, dedicated to the preservation of biological diversity and its evolutionary potential (Soule \& Wilcox, 1980). It became more formalized with the establishment of the now international Society for Conservation Biology in 1985.

At the same time support was coming from another direction, as international conservation organizations were recognizing the importance of people as central players, both driving extinction and working to prevent the loss of species (IUCN et al., 1980). Without improving the lives of the people who depend most directly on nature for their survival, such organizations argued, conservation was doomed to fail. Thus was born the concept of sustainable development, which reached out to new audiences for conservation, especially the agencies devoted to development and the private sector. Conservation for development still has critics but it has significantly increased the political profile of the importance of genes, species and ecosystems.

While conservationists often squabbled over tactics, the concept of biodiversity was being fleshed out, notably through a seminal meeting convened by the US National Research Council and the Smithsonian Institution that put the word biodiversity into the public vocabulary (Wilson,

Jeffrey A. McNeely IUCN, Rue Mauverney 28, CH-1196, Gland, Switzerland. E-mail jam@iucn.org
1988). This meeting served as a catalyst for numerous other initiatives, leading to a call for international action that went far beyond just species conservation. It included sustainable use of biological resources, sharing of the economic benefits from the use of genetic resources, and new elements for dealing with the potential and risks of the biotechnologies that were emerging from the laboratories inspired by Watson and Crick.

By 1988 a task force was assembled by the United Nations Environment Programme's Executive Director Mustafa Tolba to suggest key elements for inclusion in an international convention, which in turn led to a more formal intergovernmental working group that yielded a draft Convention on Biological Diversity (CBD). The resulting Convention was negotiated and signed at the Earth Summit in Rio de Janiero in 1992. It entered into force in 1993 and now has 193 Parties (ironically, the USA, a critical seedbed of the concept of biodiversity, has yet to ratify the CBD, based originally on concerns from the biotechnology industry but now apparently frozen in the icy partisan politics of Washington DC).

The Global Biodiversity Strategy (WRI et al., 1992), published before the CBD was agreed, called for an International Biodiversity Decade, to be adopted by the United Nations General Assembly to cover the years 1994-2003. In the event, this was overly ambitious and it was not until 2002 that the UN designated 2010 as the International Year of Biodiversity.

So what happened in the meantime? The Conference of Parties to the CBD has met nine times, with their decisions setting international standards for addressing the many issues affecting biodiversity. A biosafety protocol was agreed under the CBD on the international trade in genetically modified organisms (the 2003 Cartagena Protocol). Some 170 countries have prepared national biodiversity strategies and action plans, often with several updates. Numerous action plans were agreed by the Parties, covering everything from invasive alien species to protected areas. Guidelines were agreed on sustainable use and for conducting cultural, environmental and social impact assessments regarding developments likely to affect sacred sites and lands and waters traditionally used by indigenous and local communities. A Global Pollinators Initiative, a Global Taxonomy Initiative and a Global Strategy for Plant Conservation were agreed. A major project on The Economics of Ecosystems and Biodiversity began in 2007 and will deliver its report at the 1oth Conference of Parties, in Nagoya, Japan, in 
October 2010. The private sector has become more concerned about biodiversity and many companies include biodiversity issues in their mission statements and are carrying out actions based on the principles developed under the CBD.

Perhaps most challenging was the ambitious target agreed in 2002 by the Conference of Parties as part of its first Strategic Plan: 'To achieve by 2010 a significant reduction of the current rate of biodiversity loss at the global, regional and national level as a contribution to poverty alleviation and to the benefit of all life on Earth.' This target was impossible to meet, not least because no baseline was established and no metric was available for measuring key elements such as biodiversity (Fisher, 2009). But the target nonetheless led to substantial achievements, including the establishment of new protected areas, allocation of considerable funds, and greatly increased research on biodiversity in the oceans, freshwaters, forests and other ecosystems. Despite these efforts, the Secretariat of the CBD, drawing on national reports, has found that habitats continue to be destroyed, pollution is worsening in many places, the symptoms of climate change are becoming more alarming, more invasive species are spreading and biodiversity continues to be over-exploited (SCBD, 2010).

These are just some of the issues that governments will be addressing in Nagoya. The agenda is long, covering virtually all the issues agreed at the previous nine meetings. Despite failing to achieve the bold 2010 Target the Parties will be negotiating an even more aspirational Strategic Plan for 2011-2020. Perhaps of greatest interest to the developing countries, a new Framework for Financial Resources is to be agreed, with considerably greater resources.

At long last the Conference will also be seeking to agree a comprehensive approach to the difficult topic of access and benefit sharing, which has already gone through arduous negotiations but with many contentious issues remaining. Some governments are concerned that their indigenous peoples may try to claim ownership over genetic resources on traditional lands. Others want to ensure that any new protocol harmonizes with other related processes dealing with intellectual property. Many countries have no national legislation on access and benefit sharing, making them reluctant to agree to an international framework. Few countries are anxious to create the new bureaucracies that would be needed to effectively implement a new access and benefit sharing regime.

The discovery of the structure of DNA and the development of advanced biotechnologies have made genes more valuable and therefore worth conserving. But this has led to some unintended consequences regarding the sharing of any benefits arising, leading to governments negotiating seriously in the hope that, by the time of Nagoya, a new Protocol can be agreed on access and benefit sharing.

In signing the $\mathrm{CBD}$ governments recognized the importance of equitable sharing of the benefits arising from the use of genetic resources. But they are finding that the devil is in the details. Every government negotiates in its own interest in the first instance, and developing countries are unlikely to agree to a new Strategic Plan that does not include the resources necessary to enable them to implement it. Nor are they likely to show much enthusiasm for an access and benefit sharing regime that does not include measures to ensure they receive a fair and equitable share of the benefits from their efforts to preserve biodiversity. These are complicated issues and will need to be agreed by consensus. While hope springs eternal, the negotiators are meetinghardened veterans from 193 countries, each with its own priorities. While agreement on some issues may be fairly simple, the access and benefit sharing negotiations may resemble the acrimonious debates that led to the failure to agree on essential measures to address climate change at the 2009 Copenhagen meeting.

We can only hope that governments perceive that the access and benefit sharing regime is an essential part of conserving life on Earth and is therefore in the interests of all peoples and the other species with whom we share our fragile planet. I will be hopeful but experience suggests that many governments would rather negotiate than act.

\section{References}

FisheR, M. (2009) 2010 and all that-looking forward to biodiversity conservation in 2011 and beyond. Oryx, 43, 449-450.

IUCN, WWF (World Wildlife Fund) \& UNEP (United Nations Environment Programme) (1980) The World Conservation Strategy: Living Resources Conservation for Sustainable Development. IUCN, WWF \& UNEP, Gland, Switzerland.

Myers, N. (1979) The Sinking Ark: A New Look at the Problem of Disappearing Species. Pergamon Press, Oxford, UK.

SCBD (Secretariat of the Convention on Biological Diversity) (2010) Global Biodiversity Outlook 3. Secretariat of the Convention on Biological Diversity, Montreal, Canada.

Soulé, M.E. \& Wilcox, B.A. (eds) (1980) Conservation Biology: An Evolutionary-Ecological Perspective. Sinauer Associates, Sunderland, USA.

WiLson, E.O. (ed.) (1988) Biodiversity. National Academy Press, Washington, DC, USA.

WRI (World Resources Institute), IUCN \& UNEP (United Nations Environment Programme) (1992) Global Biodiversity Strategy: Guidelines for Action to Save, Study, and Use Earth's Biotic Wealth Sustainably and Equitably. WRI, IUCN \& UNEP, Washington, DC, USA. 